\title{
The relationship between academic integrity of online university students and its effects on academic performance and learning quality
}

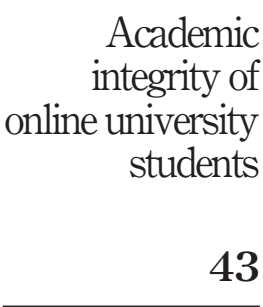

Received 31 March 2021 Revised 5 May 2021 Accepted 5 May 2021

American University of Madaba, Amman, Jordan, and

\author{
Khaled Aladwan \\ Department of Business Administration, \\ American University of Madaba, Amman, Jordan
}

\begin{abstract}
Purpose - This paper aims to investigate the relationship between academic integrity of online university students and its effects on academic performance and learning quality. The first hypothesis aimed to see if there is statistically significant relationship between academic honesty of students taking online classes and their apparent academic performance. The second hypothesis aimed to see if there is a statistically significant difference in academic integrity among male and female students. The third hypothesis aimed to see if there was a statistically significant relationship between academic honesty of students and their quality of learning.

Design/methodology/approach - This is a quantitative study; data was collected via student emails from 155 active online university students.

Findings - There was a positive linear relationship for the first hypothesis, the relationship is relatively weak as the value of Pearson correlation was (0.172). For the second hypothesis, the results showed that there was no significant difference between males and females. The results for the third hypothesis showed that there is a statistically significant relationship between academic integrity of students taking online classes and academic learning quality. This relationship is relatively strong.

Research limitations/implications - The sample size may have been a limitation for generalizing the results.

Practical implications - As a practical implication, authors recommend that education administrators focus on training their faculty members to stress and instill strong ethical values, such as academic integrity and honesty, in their students all throughout their academic journey.

Social implications - As for social implication, the embracing of ethical values in students, graduates may continue to embrace such values in the workplace which may lead to more reputable and profitable work environment where the society at large benefits.
\end{abstract}

Originality/value - This research is among the pioneers that attempted to study the connection of academic integrity and learning quality from the students' perspective.

Keywords Academic performance, Online learning, University students, Academic honesty, Academic integrity, Academic learning quality

Paper type Research paper

(C) Majda I. Ayoub/Al-Salim and Khaled Aladwan. Published in Journal of Ethics in Entrepreneurship and Technology. Published by Emerald Publishing Limited. This article is published under the Creative Commons Attribution (CC BY 4.0) licence. Anyone may reproduce, distribute, translate and create derivative works of this article (for both commercial and non-commercial purposes), subject to full attribution to the original publication and authors. The full terms of this licence maybe seen at http://creativecommons.org/licences/by/4.0/legalcode

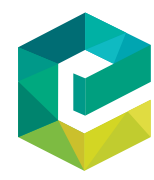

Journal of Ethics in Entrepreneurship and Technology Vol. 1 No. 1, 2021 pp. $43-60$ 2633-7436 DOI 10.1108/JEET-02-2021-0009 


\section{JEET \\ 1,1}

\section{Introduction}

Traditionally, universities have functioned in a face-to-face setting where students and faculty members meet in a classroom at a pre-arranged time, often on two or three days per week per class. These classes mainly include lectures where students receive information presented by the instructor. While these types of classes are still common at many universities and colleges, current attention has encouraged livelier student involvement in the learning process (Davies et al., 2016). Depending on the style of the instructor, generally live face-to-face lectures are more interesting and less boring especially if the instructor makes sure to include all students in discussion and participation. The latter stimulates students thinking, makes the class more enjoyable and time seems to pass rather quickly. Many academic articles were aimed to focus on the factors and determinants of quality in higher education. Some concluded that rank of university students for scholarship, additional accomplishments, parents' level of education as well as age and the institution they are receiving education from, all play a significant role on perceptions about higher education quality (Akareem and Hossain, 2016). Other researchers have found that universities' education quality differs based on the school itself. It varies based on their size, location, courses they teach, finances available, services and managerial capacity. Only a hand full of universities offer quality education while others are not concerned about the quality; the majority are reliant on part-time faculty members and poor infrastructures with low student satisfaction and students are unsure about their future employability (Rouf, 2012). Other researchers also concluded that instructor feedback and learning style were both significant predictors of high-quality online learning as well as the student satisfaction was a significant predictor of learning outcomes depending on students' learning styles (Eom et al., 2006).

Basically, for decades, the focus in higher education had been factors that revolve around the recipient of higher education such as instructors style, feedback and even the infrastructure, but little research attempted to look at the student's behavior and see if a relationship can be established between the student's ethical behavior and the learning quality the online university student is receiving. Although online learning for higher education has been in existence for decades, what makes this paper significant is that it aimed to focus on the level of academic integrity of university students while using online platforms. Also, this research aimed to see the effect of the online academic integrity of students and its relationship with the learning quality the students are receiving. Also, the researchers will be exploring how academic integrity of university students is related to apparent academic performance such as student grades. The researchers only focused on university students in the country of Jordan.

\section{Literature review}

The following is a review of the literature with respect to the variables in this research. The researchers will be touching on academic integrity of university students, discussing published literature with respect to the online university students and how misconduct usually occurs as students submit their assignments, projects, presentations and online assessments. This review will also include literature regarding academic performance of the online university students and true academic learning.

\section{Academic integrity of students}

Academic honesty and integrity are considered as the core value in our universities for learning, teaching and all academic activities. Nevertheless, the academic literature contains countless reports that proposed plagiarizing and cheating by students have 
increased in recent years (Osika, 2009). The available and ready technologies have contributed to students' behaviors going from cutting and pasting materials from the internet to sharing online quizzes and texting answers to classmates (Piascik and Brazeau, 2010).

Academic honesty represents a high priority for all universities and educational environments, it is principally of concern in courses offered online where students work independently and with less direct monitoring of their actions by their instructors. Several studies showed that students and instructors tend to believe that academic dishonesty and cheating happen more likely in an online environment which reflects the students' morals and principles (McGee, 2013; Dietz-Uhler and Hurn, 2010; Cluskey et al., 2011). Additionally, cultural differences that are unseen to the system may encourage academic dishonesty for example, when students from non-Western cultures are expected to know and operate based on Western values of behavior, those students become at a disadvantage (McGee, 2013). Payan et al. (2010) revealed that collectivist business students are more tolerant than individualist business students concerning questionable academic behaviors. Nevertheless, academic dishonesty may lead to future immoral conduct in the workplace. There is research that connects academic dishonesty among students with future unethical behavior in the workplace; international students were stated to be a largely susceptible group (Brown et al., 2019).

\section{Online class lectures}

The online learning has its own benefits and limitations; among the main benefits according to Appanna (2008) from the student's perspective is the flexibility, as it offers value to many working adults trying to balance work, family and study requirements. Appanna also added that the lack of visual cues may permit the instructor to treat all students equally. However, there are many limitations for the online synchronous learning such as students experiencing class disruption as the class remains open to students and the online students may sign on or sign off at any time during a class session. Additionally, students with learning disabilities or with language limitations may be irritated by the fast pace and textbased environment (Appanna, 2008). Moreover, if instructors rely too heavily on multiple choice and true-false questions on exams, it may not be adequate to assess students' depth of knowledge and understanding and their ability to give thorough answers as in long essay questions (Appanna, 2008). The synchronous education participation requires students to have dynamic involvement and collaboration, and some students may not be as social. Therefore, in a synchronous learning environment some students may find it a challenge to join in online live discussions (Chauhan, 2017).

Many online instructors maybe required to record their live lectures and have them available for students to retrieve at any time during the course. Kuznekoff (2020) concluded that the online lecture videos that students have access to have an effect on students' learning; however, as students spend more time watching videos, there was a reduced student learning. Kuznekoff also found that only $34 \%$ of students viewed the full lecture video, $40 \%$ watched part of the lecture video. Moreover, the average viewer watched less than $60 \%$ of each recorded video used in online classes (Kuznekoff, 2020). Fita et al. (2016) concluded that synchronous virtual e-learning is a beneficial tool for tutoring, for cooperative work both in the physical classroom and at home for remote learning. However, any new teaching tool used demands adaptability to the newer methods of teaching; therefore, more research must be conducted to evaluate the learning quality and enhance the benefits using new tools (Fita et al., 2016).

\section{Academic integrity of online university students}




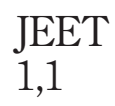

\section{Assignments/projects/presentations}

Kwong et al. (2010) conducted a study in Hong Kong and revealed that the perception of academic honesty such as the seriousness of plagiarism with respect to students may be different from faculty members. Normally students seek misconduct due to different reasons such as course overload which may create tremendous pressure on students (Kwong et al., 2010). Another research by Tabsh et al. (2017) aimed to address university students' and faculty's perceptions of plagiarism incidents, unauthorized collaborative work and copyright abuses. Faculty members suggested enforcing tougher consequences, educating students on academic honesty and assigning more proctors during exams to minimize academic integrity violations. However, both students and faculty members suggested that educating students on academic integrity and using more proctors, as well as practicing more lenient assignment deadlines and offering easier examinations maybe an option as well (Tabsh et al., 2017). Many universities offer software such as Turnitin to detect work that had been plagiarized for course assignments. McGee (2013) argues that some researchers claim that academic dishonesty could potentially be a result of course design. Many studies have been conducted attempting to find ways to improve academic honesty in e-learning for example, Amigud et al. (2017) tested a technique that aligns students' identities with the work they submit through examining patterns in their submitted assignments. Analytics allows identity automation and is able to assure authorship and resorting for an instructor only in cases where human interference is essential; this may produce more convenience, competence, honesty and integrity in the process of evaluating students' submitted work (Amigud et al., 2017).

\section{Online exams}

According to Swartz and Cole (2013), the academic institution has the main responsibility for upholding academic honesty in the classroom whether online or face-to-face, by creating a culture that will not tolerate academic dishonesty. Instructors should be supported by management to impose tough consequences for those who violate, and instructors should stress the values of ethics in the learning environment, as students will be applying such ethical values in the workplace. However, it is a fact that when a student wants to cheat, he/ she will figure out a way as cheating will never be eradicated but can be minimized (Swartz and Cole, 2013). Bearman et al. (2020) indicated that academic integrity concentrates on preparing students with the competences and morals essential to conduct ethical scholarship. On the other hand, exams' security concentrates on toughening exams to counter cheating efforts and attempts to spot any cheating that has happened. Although different objectives yet essential to make sure that students who complete their bachelor's degrees have met the desirable outcomes (Bearman et al., 2020). According to O'Connell (2016), the present philosophy toward academic integrity is affected by policy activities, such as syllabi or course outlines emphasizing academic integrity and ethical rules or conduct. Academic integrity of students is also affected by the ability of academics to teach as well as enhance the students' knowledge and acceptance of academic integrity standards (O’Connell, 2016).

The question remains; will we ever know who had taken the online assessment at home? Is it the actual student or someone else? Universities in search of conformance to the Higher Education Acts, according to Lee-Post and Hapke (2017), are advised to put in place an enduser verification solution that may authenticate a learner's identity, legitimacy and presence. Technology is improving so swiftly where universities may implement cost-effective solutions to enhance the academic integrity using sophisticated yet inexpensive authentication software and hardware. Such solutions should integrate both deterrence and 
implementation approaches to sufficiently address academic integrity (Lee-Post and Hapke, 2017). Also, some studies were conducted to compare students' performance when being watched compared to not being watched while being examined in online classes. Daffin and Jones (2018) concluded that students performed noticeably worse on proctored examinations than non-proctored examinations. The difference in performance maybe due to students' overall nervousness regarding taking the exam and is worsened by being observed during the exam. Or it is maybe due to the fact that students are unable to resort to their notes, internet sources, other students and/or their textbook, which they may potentially resort to in a non-proctored examination regardless of directions forbidding them from resorting to such resources (Daffin and Jones, 2018). There are other creative ways where the integrity of the online exams can be secured using technology. For example, Traoré et al. (2017) concluded that continuous authentication is a new technology that can be suitable in tackling a diversity of security issues. The face recognition system may record the examinations, does face recognition verifications for all students instantly and produce alarms that alert exam proctors. Such system can detect different forms of prohibited identity sharing as well as cheating on online examinations (Traoré et al., 2017).

\section{Academic performance versus true academic learning}

It is a captivating paradox in education: students can be excitedly successful on tasks and responsibilities in class but learn virtually nothing; contrariwise, students can do somewhat poorly on those same tasks but learn and absorb quite a lot (Soderstrom and Bjork, 2015).

Such scenarios and situations demonstrate one of the most substantial differences in all memory and human learning literature, namely, the difference between performance and learning. Performance denotes temporary variations in behavior or knowledge that can be observed or measured during, or shortly after, instruction. Learning, on the other hand, refers to somewhat permanent changes and development in behavior or knowledge. It is, or at least should be the goal of education (Soderstrom and Bjork, 2015). Consequently, academic dishonesty may lead to future immoral conduct in the workplace. There is research that connects academic dishonesty among students with future unethical behavior in the workplace; international students were stated to be largely susceptible group (Brown et al., 2019).

Altogether, learning is considered as a long-running process, whereas, performance is short-term. However, this means that instructors will not distinguish if their students have acquired or learned something up until after a while in which the students did not use or think about the information (Soderstrom and Bjork, 2015). Because of COVID-19 pandemic, most universities, instructors and students unexpectedly find themselves enforced to switch from physical classroom teaching and learning into using remote learning technology. Increasingly, this transformation raises tons of issues, from internet connectivity and coverage, students' questions and queries, how instructors and universities handle students' grades to how universities tackle students' evaluations of instructors. Moreover, this leads to the following question: What impact does this emergency immersion into online learning by many universities may have on faculty and students' confidence in technology-enabled learning (Lederman, 2020). The above arguments and question have been supported by the results of a study conducted by Thompson et al. (2017) which demonstrated that true academic learning and academic honesty are fully achieved through cult-learning in physical face to face classrooms. This current research asked respondents about their final grades as well as their cumulative grade point average (GPA) as a measure for their academic performance. Furthermore, the researchers aimed to examine if there is a relationship between true academic learning and academic integrity of online university students. 


\section{JEET \\ 1,1}

\section{Methodology}

The main fieldwork of the current research was conducted in Jordan that lasted a couple of months. This research addresses the gap in research concerning the relationship between the academic integrity of online university students and their true learning quality as there is shortage of such studies. Prior to the actual data collection, a draft version of the questionnaire was pilot tested, involving a sample of 27 students to obtain their perceptions and comments on the questionnaire's design and the wording of questions. The questionnaire consisted of Likert-scale questions with five options to choose from beginning with strongly disagree and ending with strongly agree. Following the pilot test, questionnaires were distributed electronically to students' emails sent by the deanship of student affairs, to guarantee that these questionnaires only would be filled by university students. The questionnaire was sent to few local universities' students, google forms were used for collecting the data for enhanced accuracy of data entry. Anonymity was guaranteed and no data was collected that could identify respondents.

The primary data was collected by using a highly structured quantitative instrument, that is, a self-administered questionnaire, the questionnaire was sent via email to 1,500 active undergraduate students enrolled in local universities; 155 filled out questionnaires with a response rate or sample size to be about $10.33 \%$. There were 97 females and 58 males who filled out the questionnaire; $120(77.9 \%)$ were Jordanians or Palestinians, $21(13.6 \%)$ were from the Middle East and North Africa. The primary data in the form of excel sheet had been numerically coded and accurately entered a statistical package for social sciences (SPSS version 26). Additionally, the current research had employed the quantitative methods to support the testing of the present concepts and theory which are comprised of different sets of research variables (academic integrity and honesty, academic performance, and quality of learning). It can be argued that quantitative methods are related to hypotheses testing (Collis and Hussey, 2014; Lewis et al., 2012). Moreover, the validity concerning the theoretical generalization can be established by using quantitative methods, and this is widespread in the field of social sciences and management studies (Neuman, 2014).

The questionnaire consisted of two parts; the first part was designed to measure the demographic characteristics, which includes gender, age and nationality and so on. To measure the Academic Performance variable, the researchers examined previous studies conducted in this perspective. Many studies specify that course grades and GPA are the most used tools to measure academic performance (York, 2015). Additionally, according to Huang (2011), we can measure academic performance via measuring self-efficacy; which led the authors of this research to add questions enquiring respondents to rate their effective online class participations or class discussions. Also, the respondents were asked to rate the quality of their research papers whether they have gotten better or worse since the switch to online learning (Huang, 2011). Moreover, presentation skills are among the important factors that have been used to measure academic performance of university students; that's why the authors of this paper added a question on the survey to rate the students' presentation skills, whether they have been enhanced as they take courses online (Shahzadi and Ahmad, 2011).

However, the second part includes questions, which had been developed to measure the study major variables to examine the following hypotheses:

H1. There is a statistically significant relationship between academic honesty of students taking online classes and their apparent academic performance.

H2. There is a statistically significant difference in academic integrity among online males and females. 
H3. There is a statistically significant relationship between academic honesty of students taking online classes and their learning quality.

\section{Results}

The research questionnaire was distributed to a random sample of 27 enrolled undergraduate students that had taken at least one class online to make sure that the statements are understandable; the language is simple and clear. Also, to make sure that the nature of the students' response to the statements does fit the intended meaning and the questionnaire measures what it's supposed to measure. Necessary tests were also carried out and necessary modifications have taken place based on the results obtained, the final version was tested again as demonstrated in the following sections.

\section{Face validity}

The validity of the research instrument was analyzed using face validity, construct validity and discriminant validity as well as other procedures to ensure the soundness of this research. For face validity, the researchers presented the questionnaire to a panel of experts with a total of five experts from different universities who are specialized in the field of education. The views and opinions of the panel were seriously considered, the required adjustments were made based on their suggestions and comments.

\section{Construct validity}

Construct validity was analyzed using the correlation coefficients between items of the questionnaire variables, the results are presented in Table 1.

Table 1 indicates the correlation that expresses the construct validity among the questionnaire items. The highest value of correlation that could be reached is (1), so a minimum value of 0.40 is considered good and acceptable correlation value (Laher, 2010). Inspecting the provided values in Table 1 , it is clear that all the mentioned correlation values were $>0.40$ in all factors suggesting good construct validity for each variable expressed by its related items.

\section{Discriminant validity}

Discriminant validity refers to the extent to which factors are distinct and uncorrelated.

Before assessing the discriminant validity $\mathrm{KMO}$ and Bartlett's tests were performed, the results are presented in Table 2.

\begin{tabular}{|c|c|c|c|c|}
\hline & $\begin{array}{l}\text { Academic integrity of the } \\
\text { online learning students }\end{array}$ & $\begin{array}{l}\text { Academic performance of the } \\
\text { online learning students }\end{array}$ & $\begin{array}{l}\text { Academic learning quality } \\
\text { of the online learning students }\end{array}$ & \\
\hline 1 & 0.621 & 0.661 & 0.679 & \\
\hline 2 & 0.805 & 0.727 & 0.668 & \\
\hline 3 & 0.730 & 0.772 & 0.700 & \\
\hline 4 & 0.777 & 0.833 & 0.590 & \\
\hline 5 & 0.790 & - & 0.583 & \\
\hline 6 & - & - & 0.625 & Table 1 \\
\hline 7 & - & - & 0.663 & 1 able 1. \\
\hline 8 & - & - & 0.677 & Correlation \\
\hline 9 & - & - & 0.761 & coefficients between \\
\hline 10 & - & - & 0.779 & the item and its total \\
\hline 11 & - & - & 0.777 & for each variable \\
\hline
\end{tabular}




\section{JEET \\ 1,1}

50

Table 2 shows the results of KMO and Bartlett's Tests including Chi-Square. KMO results of the measurement adequacy (which determines if the responses given with the statements are adequate or not), value of 0.854 are greater than cutoff point of 0.5 and therefore considered acceptable. Indicating that the data are suitable for structure detection.

The value of Chi-Square (1395.403) is greater than the tabulated value at the degree of freedom of 190 which equals to 124 at $\alpha \leq 0.05$ indicating that the data is suitable for analyses. In addition, Bartlett's test of sphericity is significant (0.000 less than 0.05$)$ which means that correlation matrix is not an identity matrix (Cerny and Kaiser, 1977).

\section{Reliability analysis}

Cronbach's alpha test was used to assess the reliability of the research instrument. Table 3 shows results for the 20 statements of the questionnaire and how closely related a set of items are as a group over the sample of respondents.

Table 3 shows that all factors Cronbach's alpha values are acceptable. The overall value is (0.894) indicating high level of reliability of the questionnaire reflecting relatively high internal consistency, since the reliability coefficient of 0.70 or higher is considered "acceptable" in the majority of social science research situations (Nunnally, 1978).

\section{Descriptive analyses}

Below, the descriptive analysis of the research tool is presented. The researchers relied on the following scale to describe the mean values based on the following equations:

(Highest weight "6" - Lowest weight “1")

Category length $=$ No. of categories " 6 "

5

Category length $=\frac{}{6}=0.83$

Accordingly, the researchers relied on the following scale to describe the mean values

$1.00-1.83$ very low

$1.84-2.67$ low

$2.68-3.51$ slightly low

$3.52-4.35$ slightly high

4.36-5.19high

5.20 - 6.00very high

Table 2.

Kaiser-Meyer-Olkin Measure of Adequacy

0.854

KMO and Bartlett's Bartlett's Test of Sphericity

Approx. Chi-Square

1395.403 tests

Degree of Freedom

190

Sig.

Table 3.

Reliability analysis through Cronbach alpha results

\begin{tabular}{lcc}
\hline & No. of Items & Cronbach's Alpha \\
\hline Academic Integrity of the online learning students & 5 & 0.799 \\
Academic Performance of the online learning students & 4 & 0.733 \\
Academic learning quality of the online learning students & 11 & 0.861 \\
All Variables & 20 & 0.894 \\
\hline
\end{tabular}


Analyzing the items of the variables, Means, standard deviations, and mean indices (MI) were calculated for each item, as demonstrated in the following sections (Figure 1).

Table 4 indicates connection problems or computer issues if I see myself running late in turning in assignment on time" factor recorded the highest mean among the factors being rated by the study sample, as it ranked the first with a mean of (2.32), while the statement no. 1 "I always resort to someone to do part or all of the work for me with my online assignments" was the least factor that was addressed as it recorded the least mean (1.79). The overall assessment degree of the Academic Integrity of the online learning students factor was rated by a mean of (2.0839). This value expresses a low level of agreement among

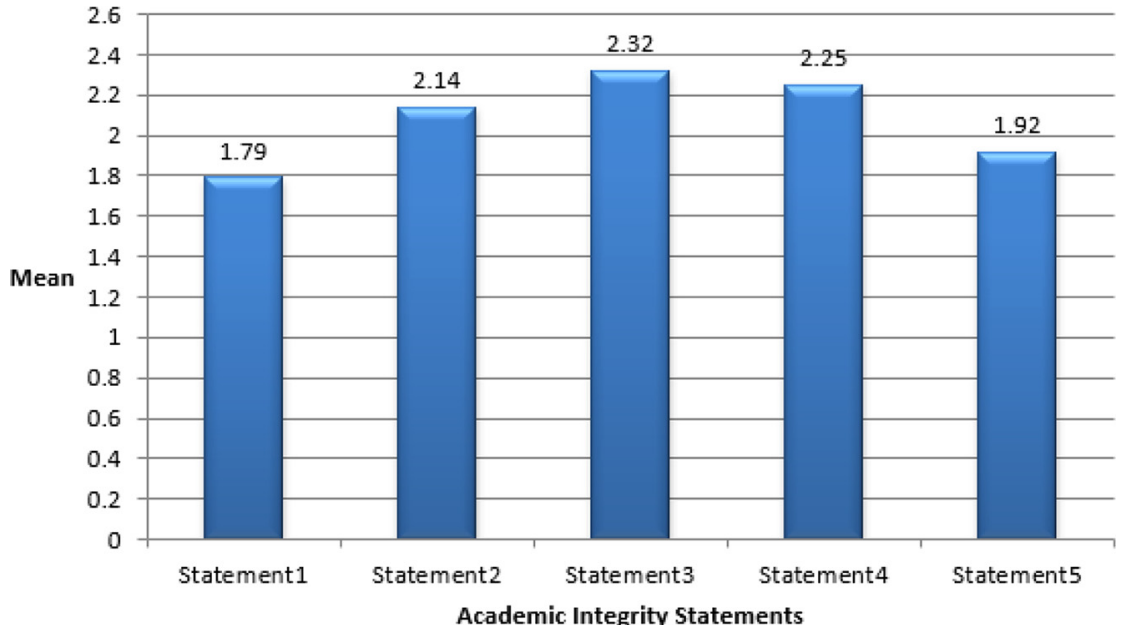

Academic Integrity Statements
Academic integrity of online university students

Figure 1.

Academic integrity of the online learning students

\begin{tabular}{|c|c|c|c|c|c|c|}
\hline No. & Items & M & $\mathrm{SD}$ & MI $(\%)$ & Level & Rank \\
\hline 3 & $\begin{array}{l}\text { I can always resort to internet connection problems or } \\
\text { computer issues if I see myself running late in turning in } \\
\text { assignment on time }\end{array}$ & 2.32 & 1.537 & $38.7 \%$ & Low & 1 \\
\hline 4 & $\begin{array}{l}\text { Online Real-time exams are easy to handle because I can } \\
\text { simply look up my answers and no one will ever know. }\end{array}$ & 2.25 & 1.501 & $37.5 \%$ & Low & 2 \\
\hline 2 & $\begin{array}{l}\text { The good thing about online assignments, Instructors } \\
\text { can never find out if I cheated by having someone do all } \\
\text { or part of the work for me. }\end{array}$ & 2.14 & 1.443 & $35.7 \%$ & Low & 3 \\
\hline 5 & $\begin{array}{l}\text { I can always resort to someone to do part or all of the } \\
\text { online exam for me or work with me to look up answers }\end{array}$ & 1.92 & 1.264 & $31.9 \%$ & Low & 4 \\
\hline \multirow[t]{2}{*}{1} & $\begin{array}{l}\text { I always resort to someone to do part or all of the work } \\
\text { for me with my online assignments. }\end{array}$ & 1.79 & 1.201 & $29.8 \%$ & Low & 5 \\
\hline & Overall Mean & 2.0839 & 1.03870 & $34.73 \%$ & Low & \\
\hline
\end{tabular}

Notes: Means description ( $1-1.83$ v. low, $1.84-2.67$ low, $2.68-3.51$ slightly low, $3.52-4.35$ slightly high and 4.36 - 5.19 high, $5.20-6 \mathrm{v}$ high)
Table 4. Means, SD and MI for academic integrity of the online learning students arranged in a descending order 


\section{JEET 1,1}

Figure 2.

Academic performance of the online learning students

\section{Table 5.}

Means, SD and MI for academic performance of the online learning students arranged in a descending order the study sample. The values of means and standard deviations, MI for the Academic Integrity of the online learning students. The statement no. 3 "I can always resort to internet (Figure 2).

Table 5 indicates the values of means and standard deviations, MI for the Academic Performance of the online learning students. The statement no. 2 "I have been participating more during online class discussions compared to on campus" factor recorded the highest mean among the factors being rated by the study sample, as it ranked the first with a mean of (3.21), while the statement no. 4 "The scores of my projects and presentations have improved noticeably since we switched to online learning" was the least factor that was addressed as it recorded the least mean (2.86). The overall assessment degree of Academic Performance of the online learning students factor was rated by a mean of (3.0145). This value expresses a slightly low level of agreement among the study sample. (Figure 3).

Table 6 indicates the values of means and standard deviation, MI for the Academic learning quality of the online learning students. The statement no. 4 "On campus lectures are much better suited than online to building my skills, knowledge and abilities for my future career" factor recorded the highest mean among the factors being rated by the study

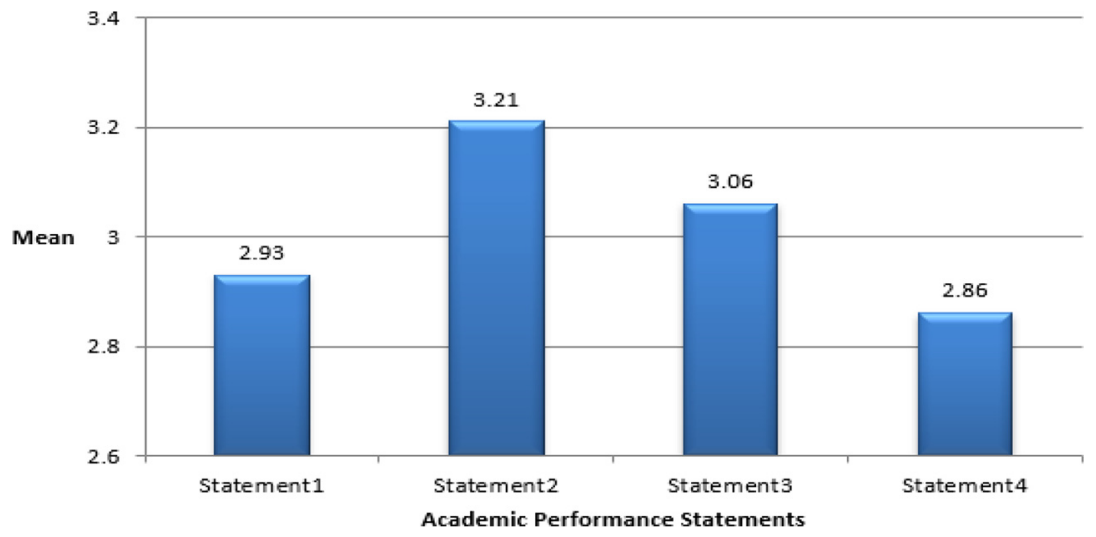

\begin{tabular}{llrrrrc}
\hline No. & Items & M & SD & MI (\%) & Level & Rank \\
\hline 2 & $\begin{array}{l}\text { I have been participating more during online class } \\
\text { discussions compared to on campus }\end{array}$ & 3.21 & 1.768 & $53.4 \%$ & Slightly Low & 1 \\
3 & $\begin{array}{l}\text { The scores of my research papers have improved } \\
\text { noticeably since we switched to online learning }\end{array}$ & 3.06 & 1.422 & $51.1 \%$ & Slightly Low & 2 \\
1 & $\begin{array}{l}\text { My grades have improved noticeably since I have been } \\
\text { taking classes online }\end{array}$ & 2.93 & 1.504 & $48.8 \%$ & Slightly Low & 3 \\
4 & $\begin{array}{l}\text { The scores of my projects and presentations have } \\
\text { improved noticeably since we switched to online } \\
\text { learning }\end{array}$ & 2.86 & 1.531 & $47.6 \%$ & Slightly Low & 4 \\
& Overall Mean & 3.0145 & 1.16330 & $50.24 \%$ & Slightly Low &
\end{tabular}

Notes: Means description ( $1-1.83$ v. low, $1.84-2.67$ low, $2.68-3.51$ slightly low, $3.52-4.35$ slightly high and $4.36-5.19$ high, $5.20-6 \mathrm{v}$ high) 
sample, as it ranked the first with a mean of (5.36), expresses a very high level of agreement among the study sample, statement no. 2 "Online Lectures are boring and difficult to learn from" factor ranked in the second place with a mean of (4.46) expresses a high level of agreement among the study sample, while the statement no. 1 "I can always resort to someone to help me with the online exams which usually enhances my final grade" was the least factor that was addressed, as it recorded the least mean (2.05), expresses a low level of agreement among the study sample. The overall assessment degree of the factor Academic learning quality of the online learning students was rated by a mean of (3.485). This value expresses a slightly low level of agreement among the study sample.

\section{Hypotheses testing}

Before testing the hypotheses, two basic assumptions must be tested to apply linear regression; normality of the data distribution of the independent variables and the level of multicollinearity among the independent variables. Skewness and Kurtosis test were used for normality, and VIF (Variance Inflation Factor test) was used for multicollinearity, the results are presented in Table 7.

Table 7 shows the skewness and Kurtosis values and the VIF results. Data are considered to be close to the normal distribution if it lies between $(-3$ and +3$)($ George and Mallery, 2002). The obtained values proved that the data is normally distributed as all obtained values lie between assigned range. Maddala (1992) mentioned that a value of VIF more than 30 is considered to be a big problem, a value more than 10 leads to untrusted with the coefficients, a value between $5-10$ reflects a moderate problem, while a value less than 5 reflects no real issue. All obtained values were less than 2 , which means that there is no multicollinearity problem between variables.

Based on the above results, testing the hypotheses can be carried on.

\section{Testing the first hypothesis}

According H1, there is a statistically significant relationship between Academic Integrity of students taking online classes and their Academic Performance. Gender as a moderation effect on the original relationship between Academic Integrity of students taking online classes and their Academic Performance.

Table 8 shows the relationship between Academic Integrity and Academic Performance directly and then under with Gender interaction, the first Model has a positive linear relationship, the relationship is relatively weak as the value of Pearson correlation is equal to (0.172) and sig. value (0.032) is less than 0.05 (Cohen, 1988).

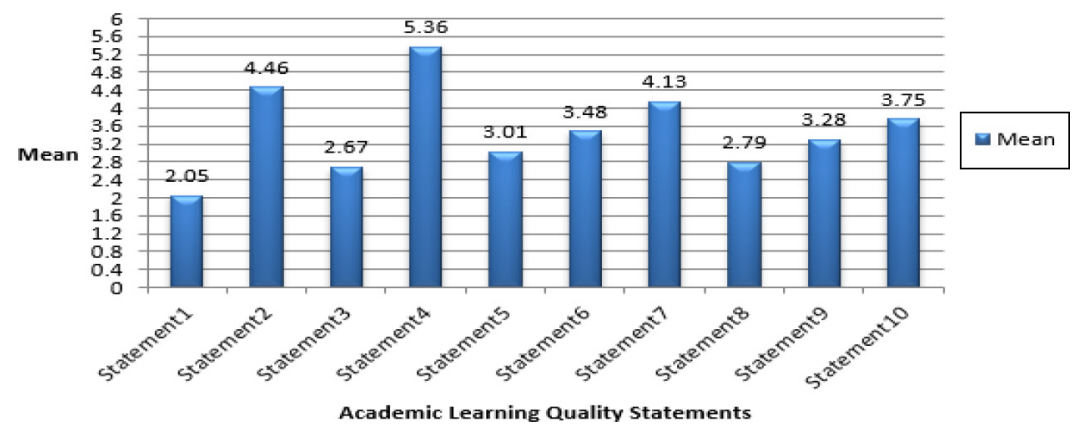

Figure 3. Analyzing the items of academic learning quality of the online learning students integrity of online university students 


\section{JEET 1,1}

Since the sig. F value is $(0.000)$ which is less than (0.05), the alternative hypothesis, $H 1$ is accepted, indicating that there is a statistically significant relationship between academic Integrity of students taking online classes and their Academic Performance. This relationship is relatively weak.

In the second Model the Gender interaction has insignificant relationship with Academic Integrity and Academic Performance, the value of Pearson correlation (R) is equal to (-0.086) while the sig. value (0.288) is greater than 0.05 . Also, the change in R Squared value is equal

\begin{tabular}{|c|c|c|c|c|c|c|}
\hline No. & Items & M & SD & MI $(\%)$ & Level & Rank \\
\hline 4 & $\begin{array}{l}\text { On campus lectures are much better suited than } \\
\text { online to building my skills, knowledge and abilities } \\
\text { for my future career }\end{array}$ & 5.36 & 1.080 & $89.4 \%$ & Very High & 1 \\
\hline 2 & Online Lectures are boring and difficult to learn from & 4.46 & 1.641 & $74.3 \%$ & High & 2 \\
\hline 7 & $\begin{array}{l}\text { I feel the quality of education I am receiving had } \\
\text { suffered tremendously since we started taking } \\
\text { classes online }\end{array}$ & 4.13 & 1.594 & $68.8 \%$ & Slightly High & 3 \\
\hline 10 & $\begin{array}{l}\text { I am not really learning much during online lectures } \\
\text { since I am rarely mentally tuned in. }\end{array}$ & 3.75 & 1.715 & $62.5 \%$ & Slightly High & 4 \\
\hline 6 & $\begin{array}{l}\text { On Campus exams require more studying and } \\
\text { preparation since you have no resources to get your } \\
\text { answers from during the exam }\end{array}$ & 3.48 & 1.778 & $58.1 \%$ & Slightly Low & 5 \\
\hline 11 & $\begin{array}{l}\text { I can always sign into a live class lecture and do my } \\
\text { own thing unrelated to class }\end{array}$ & 3.35 & 1.590 & $55.9 \%$ & Slightly Low & 6 \\
\hline 9 & $\begin{array}{l}\text { My presentation skills have not improved since we } \\
\text { switched to online. I can just read the slides without } \\
\text { turning on the camera; no need for rehearsal! If asked } \\
\text { to turn the camera on I can easily say it does not } \\
\text { work! }\end{array}$ & 3.28 & 1.686 & $54.7 \%$ & Low & 7 \\
\hline 5 & $\begin{array}{l}\text { I find myself preparing for exams in way less time } \\
\text { for online classes compared to on campus exams; I } \\
\text { just have to worry about getting all my resources } \\
\text { available for me during online exams. }\end{array}$ & 3.01 & 1.671 & $50.2 \%$ & Slightly Low & 8 \\
\hline 8 & $\begin{array}{l}\text { At this point my main concern is to graduate with a } \\
\text { degree regardless of the minimal learning I am } \\
\text { receiving from the online courses. }\end{array}$ & 2.79 & 1.702 & $46.5 \%$ & Slightly Low & 9 \\
\hline 3 & $\begin{array}{l}\text { The good thing about online lectures is that I can } \\
\text { sign into class and never have to participate }\end{array}$ & 2.67 & 1.612 & $44.5 \%$ & Low & 10 \\
\hline \multirow[t]{2}{*}{1} & $\begin{array}{l}\text { I can always resort to someone to help me with the } \\
\text { online exams which usually enhances my final grade }\end{array}$ & 2.05 & 1.266 & $34.1 \%$ & Low & 11 \\
\hline & Overall Mean & 3 & 1.02676 & $58.08 \%$ & lightly Low & \\
\hline
\end{tabular}

Table 6.

Means, SD and MI for academic learning quality of the online learning students arranged in a descending order
Notes: Means description ( $1-1.83$ v. low, $1.84-2.67$ low, $2.68-3.51$ slightly low, $3.52-4.35$ slightly high and $4.36-5.19$ high, $5.20-6 \mathrm{v}$ high)
Table 7.

Normality indicator and the VIF test for multicollinearity

\begin{tabular}{lrrr}
\hline Variables & Skewness & Kurtosis & VIF \\
\hline Academic Integrity of the online learning students & 1.311 & 1.835 & 1.684 \\
Academic Performance of the online learning students & 0.115 & -0.914 & 1.175 \\
Academic learning quality of the online learning students & -0.188 & -0.643 & 1.692 \\
\hline
\end{tabular}


to 0.001 , which means that the ability of Gender interaction to explain the variation in the relationships between Academic Integrity of students taking online classes and their Academic Performance did not significantly change. The sig.t ( $p$-value) is equal to (0.6930) which is greater than 0.05 , accordingly, is rejected as there is no statistically significant effect of the demographic variable Gender on the original relationships between Academic Integrity of students taking online classes and their Academic Performance.

Testing the second hypothesis

There is a statistically significant relationship between Academic Integrity of students taking online classes and the Academic Learning Quality. Gender has a moderation effect on the original relationship between Academic Integrity of students taking online classes and their Academic Performance.

Table 9 shows the relationship between Academic Integrity and Academic Learning Quality directly and then under with Gender interaction. The first Model has a significant strong positive linear relationship, where the value of Pearson correlation is equal to (0.571) and the sig. value $(0.000)$ is less than 0.05 (Cohen, 1988). Since the sig. F value is $(0.000)$ which is less than (0.05), the alternative hypothesis, is accepted, which means that there is a statistically significant relationship between academic Integrity of students taking online classes and Academic Learning Quality. This relationship is relatively strong.

In the second Model, the Gender interaction has insignificant relationship with Academic Integrity and Academic Learning Quality, the value of Pearson correlation (R) is equal to (0.044) while the sig. value (0.583) is greater than 0.05. Also, the change in R Squared value is equal to 0.003 , which means that the ability of Gender interaction to explain the variation in the relationships between Academic Integrity of students taking online classes and their Academic Learning Quality did not significantly change. The sig. $t$ ( $p$-value) is equal to (0.406) which is greater than 0.05 , accordingly, the alternative hypothesis is rejected whereas there is no statistically significant effect of the demographic variable Gender on the original relationships between Academic Integrity of students taking online classes and their Academic Learning Quality.

\begin{tabular}{|c|c|c|c|c|c|c|c|}
\hline Model & Variables & $\mathrm{R}$ & $\beta$ & $\mathrm{t}$ & Sig. $\mathrm{t}$ & $\mathrm{F}$ & Sig. $F$ \\
\hline Model 1 & Academic Integrity and Academic Performance & $\begin{array}{c}0.172 \\
\text { Sig. }=0.032\end{array}$ & 0.193 & 2.160 & 0.032 & 4.666 & 0.032 \\
\hline Model 2 & $\begin{array}{l}\text { Gender Interaction } \\
\qquad \operatorname{Model}\left(\mathrm{R}^{2}=0.030\right), \operatorname{Model} 2\left(\mathrm{R}^{2}=0.031, \mathrm{R}\right.\end{array}$ & $\begin{array}{c}-0.086 \\
\text { Sig. }=0.288\end{array}$ & -0.032 & -0.396 & 0.693 & 2.399 & 0.094 \\
\hline
\end{tabular}

Table 8.

Multiple linear regression for academic integrity of students and their academic performance along with gender interaction

\begin{tabular}{|c|c|c|c|c|c|c|c|}
\hline Model & Variables & $\mathrm{R}$ & $\beta$ & $\mathrm{t}$ & Sig. t & $\mathrm{F}$ & Sig. F \\
\hline Model 1 & Academic Integrity and Academic Learning Quality & $\begin{array}{c}0.571 \\
\text { Sig. }=0.000\end{array}$ & 0.564 & 8.604 & 0.000 & 74.027 & 0.000 \\
\hline Model 2 & $\begin{array}{l}\text { Gender Interaction } \\
\qquad \text { Model1 }\left(\mathrm{R}^{2}=0.326\right) \text {, Model } 2\left(\mathrm{R}^{2}=0.329, \mathrm{R}^{2} \text { chang }\right.\end{array}$ & $\begin{array}{c}0.044 \\
\text { Sig. }=0.583 \\
\text { ged }=0.003, \mathrm{~F}\end{array}$ & 0.050 & 0.833 & 0.406 & 37.286 & 0.000 \\
\hline
\end{tabular}

Table 9. Multiple linear regression for academic integrity of students and the academic learning quality along with gender interaction 


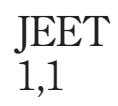

\section{Discussion and conclusion}

The descriptive data for this study indicated that the statement on the survey that addressed academic integrity of the online learning students had the highest mean, as follows: "I can always resort to internet connection problems or computer issues if I see myself running late in turning in assignment on time." Almost $15.5 \%$ of students agreed and strongly agreed with this statement. Evidently, these students admitted that they would resort to dishonest excuses to lessen the consequences of such behavior.

Also, according to the descriptive data for this study, it indicated that the statement that addressed Academic Performance of the online learning students, had the highest mean, the statement of the survey was as follows; "I have been participating more during online class discussions compared to on campus"; $29 \%$ of respondents agreed and strongly agreed with the statement. This can be a pointer, which could mean that those students who were relatively shy to participate in face to face class discussions were encouraged more to participate in the online synchronous environment, since the online camera was never mandatory to be on for students.

Additionally, according to this study's descriptive data, the statement that addressed Academic Learning quality of the online learning students which had the highest mean, the statement of the survey as follows; "On campus lectures are much better suited than online to building my skills, knowledge and abilities for my future career". Approximately $85 \%$ of respondents agreed and strongly agreed with this statement. It seems that students put much more faith in the face-to-face learning environment as opposed to online learning environment. One potential reason for such overwhelming response is that the online learning environment is very new in the region and is still frowned upon by parents and faculty members.

While the statement in this category that says, "Online Lectures are boring and difficult to learn from" scored the second highest in this category and slightly over $56 \%$ of respondents agreed and strongly agreed with this statement. Seemingly, more than half the respondents believed that online lectures are not as exciting as face to face lectures and are difficult to learn from. Additionally, in this same category the statement that says, "I feel the quality of education I am receiving had suffered tremendously since we started taking classes online" $46 \%$ of respondents agree or strongly agree with this statement; this can be an alarming finding that almost half the respondents perceived that the online education was not of the expected quality. The latter result maybe contributed to the fact that the online line learning platform was imposed on all due to the COVID19 pandemic, and for some; it may not have been the optimal way of receiving education.

In conclusion, Academic Integrity of students taking online classes does affect Academic Performance in a weak way, which means that there are more important factors that affect the Academic Performance of students. Both male and female students answered the same way, as gender did not make any difference in this result.

Here are some pointers for the readers to think about is that the result of the first hypothesis does not mean that if students are honest academically then their academic performance will be high; however, this may mean that some students who are academically honest may or may not perform well academically depending on how much effort they put into the course and other individual factors such as IQ levels or their interest in the topic. However, some students who are not academically honest yet may perform very well on online tests, projects and other means of evaluation which is not a valid indicator of quality of learning.

A formal education must be shared with students on the importance of academic integrity; for such education to be successful there must be collaboration between faculty members, staff as well as students (Garza Mitchell and Parnther, 2018). 
The relationship between Academic Integrity and Academic Learning Quality was measured in the third hypothesis which means that there is a statistically significant relationship between academic Integrity of students taking online classes and Academic Learning Quality. This relationship is relatively strong (0.57) The Gender interaction has insignificant relationship with Academic Integrity and Academic Learning Quality which means that the higher the academic integrity of online students, the higher their learning quality would be. This brings the researchers to point out the idea that when more students are practicing academic integrity, the more the assessments of their performance are accurate and more indicative of their true knowledge and skills. Additionally, The researchers' last pointer for readers to think about; which is how online education divisions would distinguish themselves from competition, and how universities can market their online education in a way that would offer a competitive advantage and still allow them to stand behind their claims of offering high quality online education where it truly is building the skill, knowledge and abilities of online students.

The study established that there is a difference between academic performance and academic learning which is in agreement with Soderstrom and Bjork (2015) mentioned in the literature review where learning and its quality should be the focus of educators and not performance as learning carries on for a long time. Therefore, the researchers conclude that educators need to aggressively educate online university students about the importance of academic honesty since it was concluded in this study that academic honesty or integrity is directly and strongly related to the learning quality. The latter conclusion is in agreement with (Bearman et al. 2020); O'Connell, 2016; Tabsh et al., 2017) as mentioned in the literature review. The use of technology may minimize academic dishonesty and could enhance the learning quality through the assurance of authorship via different means (Amigud et al., 2017; Lee-Post and Hapke, 2017; Traoré et al., 2017). What is more important here however, is for education administrators to focus on training their faculty members to be stressing and instilling strong ethical values such as academic integrity/honesty, in their students from the very beginning and all throughout their academic journey. Once such ethical values are embraced, graduates may continue to embrace such values in the workplace. The work environment becomes much healthier when it is crowded with high integrity employees and leaders which may lead to better reputation of the organization they work for, and ultimately more sustainable profits and societies, at large, benefit.

The data was collected from 155 students which is not necessarily a very large sample that may have resulted in a type II error or may have reduced the strength of the study which can be a potential limitation. Additionally, due to the quantitative nature of this research, it lacked depth however, for future research it is recommended to use interviews with online university students to get more in depth responses as to the effectiveness in gaining knowledge, desired workplace skills and abilities, and how academic integrity of online students, from the students standpoint, can be improved.

\section{References}

Akareem, H.S. and Hossain, S.S. (2016), "Determinants of education quality: what makes students' perception different?”, Open Review of Educational Research, Vol. 3 No. 1, pp. 52-67, doi: 10.1080/ 23265507.2016.1155167.

Amigud, A., Arnedo-Moreno, J., Daradoumis, T. and Guerrero-Roldan, A.-E. (2017), "Using learning analytics for preserving academic integrity", The International Review of Research in Open and Distributed Learning, Vol. 18 No. 5, doi: 10.19173/irrodl.v18i5.3103. 


\section{JEET 1,1}

Appanna, S. (2008), "A review of benefits and limitations of online learning in the context of the student, the instructor and the tenured faculty", International Journal on E-Learning.

Bearman, M. Dawson, P. O’Donnell, M. Tai, J. and Jorre de St Jorre, T. (2020), "Ensuring academic integrity and assessment security with redesigned online delivery [PDF]", Deakin University, Melbourne, available at: http://dteach.deakin.edu.au/2020/03/23/academic-integrity-online/

Brown, T., Isbel, S., Logan, A. and Etherington, J. (2019), "Predictors of academic honesty and success in domestic and international occupational therapy students", Irish Journal of Occupational Therapy, Vol. 47 No. 1, pp. 18-41, doi: 10.1108/ijot-12-2018-0022.

Cerny, B.A. and Kaiser, H.F. (1977), "A study of a measure of sampling adequacy for factor-analytic correlation matrices", Multivariate Behavioral Research, Vol. 12 No. 1, pp. 43-47, doi: 10.1207/ s15327906mbr1201_3.

Chauhan, V. (2017), "Synchronous and asynchronous learning", Imperial Journal of Interdisciplinary Research (IJIR), available at: www.onlinejournal.in/IJIRV3I2/231.pdf

Cluskey, G.R., Jr, Ehlen, C.R. and Raiborn, M.H. (2011), “Thwarting online exam cheating without proctor supervision [PDF]", Journal of Academic and Business Ethics, available at: www.aabri. com/manuscripts/11775.pdf

Cohen, J. (1988), Statistical Power Analysis for the Behavioral Sciences, 2nd ed., Routledge.

Collis, J. and Hussey, R. (2014), Business Research, 3rd ed., Springer Nature.

Daffin, L., Jr and Jones, A. (2018), "Comparing student performance on proctored and non-proctored exams in online psychology courses", Online Learning, Vol. 22 No. 1, doi: 10.24059/olj. v22i1.1079.

Davies, T.L. Cotton, V.K. and Korte, L. (2016), "Student usage and perceptions of the value of recorded lectures in a traditional face-to-face (F2F) class [PDF]", Journal of College Teaching and Learning. Retrieved September 13, 2020, available at: https://files.eric.ed.gov/fulltext/EJ1108348. pdf

Dietz-Uhler, B. and Hurn, J. (2010), "Discouraging academic dishonesty in online courses", American Society for Clinical Laboratory Science, Vol. 23 No. 4, pp. 71-77, doi: 10.29074/ascls.23.4.194.

Eom, S.B., Wen, H.J. and Ashill, N. (2006), "The determinants of students' perceived learning outcomes and satisfaction in university online education: an empirical investigation*”, Decision Sciences Journal of Innovative Education, Vol. 4 No. 2, pp. 215-235, doi: 10.1111/j.1540-4609.2006.00114.x.

Fita, A., Monserrat, J.F., Moltó, G., Mestre, E.M. and Rodriguez-Burruezo, A. (2016), "Use of synchronous e-learning at university degrees", Computer Applications in Engineering Education, Vol. 24 No. 6, pp. 982-993, doi: 10.1002/cae.21773.

Garza Mitchell, R.L. and Parnther, C. (2018), "The shared responsibility for academic integrity education”, New Directions for Community Colleges, Vol. 2018 No. 183, pp. 55-64, doi: 10.1002/ cc.20317.

George, D. and Mallery, P. (2002), Spss for Windows Step by Step: A Simple Guide and Reference, 11.0 Update (4th Edition), 4th ed., Allyn and Bacon.

Huang, S. (2011), "Predicting students' academic performance in college using a new noncognitive measure: an instrument design and a structural equation exploration of some noncognitive attributes and academic performance", Unpublished doctoral dissertation, Ohio State University.

Kuznekoff, J.H. (2020), "Online video lectures: the relationship between student viewing behaviors, learning, and engagement", Association for University Regional Campuses of Ohio, available at: https://doi.org/http://search.ebscohost.com/login.aspx?direct=true\&db=ehh\&AN=143181442\& site $=$ ehost-live

Kwong, T., Ng, H., Mark, K. and Wong, E. (2010), "Students' and faculty's perception of academic integrity in Hong Kong", Campus-Wide Information Systems, Vol. 27 No. 5, pp. 341-355, doi: $10.1108 / 10650741011087766$. 
Laher, S. (2010), "Using exploratory factor analysis in personality research: best-practice recommendations", SA Journal of Industrial Psychology, Vol. 36 No. 1, doi: 10.4102/sajip. v36i1.873.

Lederman, D. (2020), "Most teaching is going remote. Will that help or hurt online learning? | inside higher ed", available at: www.insidehighered.com/digital-learning/article/2020/03/18/mostteaching-going-remote-will-help-or-hurt-online-learning

Lee-Post, A. and Hapke, H. (2017), "Online learning integrity approaches: current practices and future solutions”, Online Learning, Vol. 21 No. 1, doi: 10.24059/olj.v21i1.843.

Lewis, M.P., Thornhill, P. and Saunders, A. (2012), Research Methods for Business Students, 6th ed., Pearson Education Limited.

McGee, P. (2013), "Supporting academic honesty in online courses", The Journal of Educators Online, Vol. 10 No. 1, doi: 10.9743/JEO.2013.1.6.

Maddala, G.S. (1992), Introduction to Econometrics, 2nd ed., Macmillan Pub Co.

Neuman, W.L. (2014), Social Research Methods: Pearson New International Edition: Qualitative and Quantitative Approaches, 7th ed., Pearson Higher Education, available at: http://letrunghieutvu. yolasite.com/resources/w-lawrence-neuman-social-research-methods_-qualitative-and-quantitativeapproaches-pearson-education-limited-2013.pdf

Nunnally, J.C. (1978), Psychometric Theory (Mcgraw-Hill Series in Psychology), 2nd ed., Mcgraw-Hill College.

O'Connell, J. (2016), "Networked participatory online learning design and challenges for academic integrity in higher education", International Journal for Educational Integrity, Vol. 12 No. 1, doi: 10.1007/s40979-016-0009-7.

Osika, E.R. (2009), "Assessing online learning: strategies, challenges and opportunities: assessing student learning online: it's more than multiple choice [PDF]", Magna Publications, Inc, available at: www.facultyfocus.com/wp-content/uploads/images/AssessingOnlineLearning-OC.pdf

Payan, J., Reardon, J. and McCorkle, D.E. (2010), "The effect of culture on the academic honesty of marketing and business students", Journal of Marketing Education, Vol. 32 No. 3, pp. 275-291, doi: 10.1177/0273475310377781.

Piascik, P. and Brazeau, G.A. (2010), "Promoting a culture of academic integrity", American Journal of Pharmaceutical Education, Vol. 74 No. 6, p. 113, doi: 10.5688/aj7406113.

Rouf, M.A. (2012), "Perception of factors affecting the quality of higher education: a study on selected private universities in Bangladesh (2012)", International Journal of Information, Business and Management, Vol. 4 No. 2, pp. 3-12, available at SSRN: https://ssrn.com/abstract=2565234

Shahzadi, E. and Ahmad, Z. (2011), "A study on academic performance of university students", ResearchGate, available at: www.researchgate.net/publication/266736633_A_STUDY_ON_ ACADEMIC_PERFORMANCE_OF_UNIVERSITY_STUDENTS?channel=doi

Soderstrom, N.C. and Bjork, R.A. (2015), "Learning versus performance", Perspectives on Psychological Science, Vol. 10 No. 2, pp. 176-199, doi: 10.1177/1745691615569000.

Swartz, L.B. and Cole, M.T. (2013), "Students' perception of academic integrity in online business education courses", Journal of Business and Educational Leadership, Vol. 4, pp. 102-112, available at: https://doi.org/http://search.ebscohost.com/login.aspx?direct=true\&db=bth\&AN= $103044609 \&$ site $=$ ehost-live

Tabsh, S.W., Abdelfatah, A.S. and El Kadi, H.A. (2017), "Engineering students and faculty perceptions of academic dishonesty", Quality Assurance in Education, Vol. 25 No. 4, pp. 378-393, doi: 10.1108/ qae-03-2017-0005.

Thompson, L.W., Bagby, J.H., Sulak, T.N., Sheets, J. and Trepinski, T.M. (2017), “The cultural elements of academic honesty", Journal of International Students, Vol. 7 No. 1, pp. 136-153, doi: 10.32674/ jis.v7i1.249. 
JEET

1,1

Traoré, I., Nakkabi, Y., Saad, S., Sayed, B., Ardigo, J.D. and de Faria Quinan, P. (2017), "Ensuring online exam integrity through continuous biometric authentication", Information Security Practices, Springer International Publishing, pp. 73-81, doi: 10.1007/ 978-3-319-48947-6_6.

York, T.T. (2015), "Defining and measuring academic success”, ScholarWorks@UMass, Amherst, available at: https://scholarworks.umass.edu/pare/vol20/iss1/5

\section{Further reading}

Manly, B.F. (2005), Multivariate Statistical Methods: A Primer, Third Edition, 3rd ed., Chapman and Hall.

\section{Corresponding author}

Majda I. Ayoub/Al-Salim can be contacted at:m.ayoub@aum.edu.jo

For instructions on how to order reprints of this article, please visit our website: 